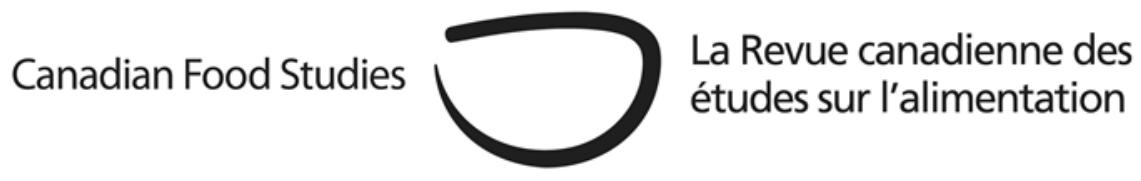

Original Research Article

\title{
Community orchards and Hyde's theory of the gift
}

Jennie K. Barron

Selkirk College

\begin{abstract}
Food scholars and advocates have long asserted that commodification is one of the fundamental injustices of our dominant, industrial food system, as it stands in direct opposition to the notion of food as a human right. The informal social economy, with its concerns for solidarity, participation, service, and community building, offers examples of what de-commodificationthat holy grail of food justice - might look like. This article reports on one particular informal social economy manifestation of decommodification, the community orchard. The author argues that decommodification must be seen not only as the absence of commodity production but as the presence of a different economy and underlying ethos - that of the gift. Lewis Hyde's theory of the gift provides a lens through which to understand the profound ways that gifting changes community orchardists' relationships to land, to food, to labour, and to those who co-produce and enjoy the fruit with them. Gift theory also furthers our understanding of food commons (of which the community orchard is but one example) as decommodified spaces. The author suggests that theorizing community orchards through the lens of gift theory provides insight into the values and mindsets that characterize non-commodity-oriented food production, which is a necessary step in the direction of innovation and the development of models that are more ecological, community-oriented, and just.
\end{abstract}

Keywords: community orchard; decommodification; commons; community garden; food sovereignty; urban space

*Corresponding author: jbarron@selkirk.ca

DOI: $10.15353 / c f s-r c e a . v 6 i 3.358$ 


\section{Introduction}

In his 2012 book, Rebel Cities, David Harvey describes "liminal social spaces of possibility where 'something different' is not only possible, but foundational for the defining of revolutionary trajectories" (xvii). The social economy (particularly in its informal manifestations) seems as good a place as any to seek out such spaces of possibility, where concerns for solidarity, participation, service, and community building are as important, if not more important, than profit or revenue generation (Canadian Social Economy Research Partnership, n.d., p. 3). In the realm of food, one quintessential expression of the social economy may be found in the community orchard, a novel variant of the community garden that aims not only to embody these pro-social values, but to operationalize them in a most radical form-decommodified collective self-provisioning on publicly accessible land - in other words, fruit grown by volunteers for sharing, often as a gift to the community at large. In this article, I present the view that the seemingly idealistic model of community orchards may well contain the seeds of a revolutionary trajectory, founded on the decommodification of food.

What follows is drawn from a larger work of doctoral research conducted in 2016 and 2017 at nine community orchards in three Canadian cities - Vancouver, Victoria, and Torontoin which I explored the meaning and purpose of community orchards to those who create and maintain them (Barron, 2018). Research involved site visits, document review, and extended semi-structured interviews with 32 very involved community orchardists, several of whom I have remained engaged with in ongoing conversation. I also interviewed two people within the City administrations in Vancouver and Victoria whose work involves supporting community gardens and orchards, and the Toronto city councilor who represents the ward that includes Ben Nobleman Community Orchard.

I wanted to study orchards that were relatively well established — at minimum, five years old - and where there was a solid core group of people who were actively and regularly using the space and/or contributing to its upkeep. In the end, the sites I chose included Copley Community Orchard, Strathcona Community Garden, Jonathan Rogers Park, and Norquay Learning Orchard (all in Vancouver); Spring Ridge Commons, Fernwood Community Orchard, and Banfield Community Orchard (Victoria); Welland Community Orchard (View Royal/Greater Victoria); and Ben Nobleman Community Orchard (Toronto).

It was not my aim to identify or comprehensively survey every single community orchard in these three cities. Rather, following an extensive environmental scan and preliminary site visits, I chose to take a case study approach, focusing on a limited number of orchards through in-depth exploration of the perspectives of those most intimately involved. As cases are "neither entirely unique nor entirely representative of a phenomenon" (Baxter, 2010, p. 86), I chose to look at a moderate number of cases to balance the particular and that which might be generalizable. My goal was to bring together a mix of different narratives that collectively illustrate the complexity — and possible ambiguity_of community orcharding as a social 
phenomenon. To ensure diverse perspectives, I chose to study orchards of varying sizes, some very established and others quite new, some thriving and some struggling, those located both within and outside of city parks, with varying degrees of tenure security and incorporation into city operations. My sites also included one food forest; one orchard that seems more like a botanical garden because it aims to demonstrate and propagate as many different varieties of fruit trees as possible; one orchard that is part of a community garden; one that doesn't call itself an orchard but a commons; some orchards that are overseen by non-profits; and others that are completely community-run.

In the dissertation, I forward the view that community orchards are much less about the fruits produced within them and more about the production of urban space as a new kind of commons. I also argue that one of the ways community orchards are instantiating or reviving the commoning ideal is by decommodifying exchange - that is, by demonstrating that food, and the labour necessary for its production, can be procured without the direct exchange of money. ${ }^{1}$ In so doing, community orchards end up having less to do with what volunteer orchardists get (i.e., free fruit) and more to do with what they give through the medium of the orchards - to themselves, to each other, to the land, and to their communities. The article that follows is adapted from my chapter on decommodification. As such, it represents only a small piece of a much bigger puzzle and may prompt questions that cannot be answered satisfactorily in the space available. Nonetheless, I will attempt to flag some important issues, to be taken up in future publications.

First, let me clarify that I do not suggest that all our food can or should be produced by volunteers. I $d o$, however, believe that understanding economies that move us away from commodification is important and that looking at examples — even micro-scale — might be instructive. For twenty years or more, food scholars have been asserting that commodification is one of the fundamental injustices of our dominant, industrial food system, as it stands in direct opposition to the notion of food as a human right (Magdoff, 2012; Rosset, 2006) and is a major driver of price volatility and hunger (Alkon \& Mares, 2012; Hassanein, 2003; Johnston, 2008; Welsh \& MacRae, 1998). Consequently, both food scholars and activists (e.g., Heynen, 2012; Vivero Pol, 2013) have advocated for basic life goods like food to be met through noncommodity channels, "insulated from the values and ethics of the conventional food system" (Wilson, 2013, p. 730-731).

Many authors (e.g., Eizenberg, 2012; Follmann \& Viehoff, 2015; Johnston, 2008; Linn, 2007; Tornaghi, 2014) have identified the potential of community gardens to function as decommodified spaces, due to the qualities that make them inherently subversive of the commodity

\footnotetext{
${ }^{1}$ To be clear, there are some costs associated with community orcharding - e.g., for tools, seedlings, mulch, compost; sometimes these are donated by local businesses or the City. The land for community orchards is public, and occasionally, groups incur costs to lease it (usually very minimal). Sometimes municipalities offer a stipend for a very part-time volunteer coordinator. But there is no direct exchange of either fruit or services for money, and the bulk of the labour, sometimes all of it, is performed by volunteers.
} 
form - namely, the way they view food as a public good and prioritize its equitable distribution over profit (McClintock, 2014, p. 148). ${ }^{2}$ Few scholars, however, have explored the decommodified nature of community gardens (or orchards) in depth, to articulate what a decommodified space $i s$, rather than just what it is not and why exactly that matters. If we want to foster innovation and aid the development of models that are more sustainable and more just, it might help to understand the values and mindsets that characterize non-commodity-oriented food production. In this article, I argue that the decommodified spaces of community orchards are illuminating in this regard because of the profound ways in which decommodification alters participants' relationships to land, to labour, and to those who co-produce and enjoy the fruit with them.

An invitation to community orchards

A community orchard is an orchard that is cared for, cooperatively, by some community of people, and that is managed for the benefit of members and/or the community at large, rather than for private profit (Ames, 2013). Community orchards are similar in some ways to the concept of public produce, popularized by Darrin Nordahl (2009, 2014). But where public produce is essentially edible urban landscaping, in which fruit and nut-bearing trees, bushes, and herbs are provided and maintained by municipal staff, and/or individuals or private businesses operating in an ad hoc manner as individuals or disconnected entities, community orchards are foremost the products of community members taking initiative and acting collectively (corralling varying degrees of municipal support). This difference is significant because self-organized collective action is what characterizes the commons as a realm beyond both market and state (Bollier \& Helfrich, 2012).

The community orcharding movement began in the United Kingdom (UK) in 1992 as an initiative of citizens who were concerned about abandoned orchards, and orchards that had already been lost to development, and who wished to preserve them out of concern for reviving heritage fruit varieties and their related historical community identities, as much as for enhancing green space and promoting healthy eating (Ames, 2013; Department for Communities and Local

\footnotetext{
${ }^{2}$ Others-e.g., Guthman, 2008, and Pudup, 2008 - have criticized community gardens for buttressing capitalism, a critique that prompts us to ask whether commoning should be seen as an emancipatory development or an acquiescence to the neoliberal state's withdrawal from responsibilities for social welfare. I believe this argument would make sense if the primary purpose of community orchards were to improve household food security. While this may have been originally the intention of some orchard initiators, interviewees made it clear to me that community orchards serve ends and fulfill needs that go well beyond those we might expect, or want, the state to fulfill. Intangible benefits include community building, skill building, shared governance of urban space, and the revival of the concept of the commons. Food production is undoubtedly still at the core of these endeavours, but not in a productivist way. Instead, it is embedded in the larger social and ecological contexts of these very multifunctional spaces.
} 
Government (DCLG), 2011; King \& Clifford, 2011). In North America, community orchards have developed somewhat differently. They tend to be located in cities and to have been planted anew, rather than being reclaimed older commercial orchards in rural areas, as many are in the UK. They tend to reflect a concern for food security and sovereignty, either at the community level or at the systems level, though heritage preservation is also important to many advocates. Most community orchards are located in municipal parks or on other publicly owned lands, but they may also be found on the grounds of housing co-ops, churches, group homes, food banks, and schools. North American cities with significant community orchards include Vancouver, Victoria, Toronto, Bloomington, Chicago, Philadelphia, Portland, and Seattle (Ames, 2013; Betz, 2014); other Canadian cities with community orchards planted in the last 5-10 years include Winnipeg, Halifax/Dartmouth, Kamloops, Guelph, Airdrie, Sackville, and Yellowknife. The community orchards I studied, and which are referred to in this article, are Ben Nobleman (Toronto); Strathcona, Copley, Norquay, and Jonathan Rogers (Vancouver); and Banfield, Fernwood, Welland, and Spring Ridge Commons (Greater Victoria) (see Table 1).

Community orchards typically consist of fruit trees - not only the familiar apple, plum, and pear (usually heirloom varieties, since they are less susceptible to pests and often taste better) but also less common fruits like persimmon, fig, and paw-paw, which grow in the relatively mild climate of Vancouver Island - as well as berry bushes, raspberry canes, grapevines, hardy kiwi, and the like. Organizationally, community orchards may involve two or three parties: a local community group, which assumes responsibility for maintenance and for harvesting the fruit and distributing it; a landowner, which in most cases is a municipality; and sometimes a non-profit organization, which may provide training and/or technical support.

Community orcharding in Canada and the U.S. can be characterized as an outgrowth or evolution of the community gardening movement. However, unlike community gardens, which are typically divided into individually maintained plots or allotments, community orchards are typically maintained through group effort and harvested in a cooperative manner; they are not easily subdivided. Growing community orchards tends, then, to be much more of a collective endeavour. People in community orchards regularly share materials, tasks, meals, and expertise - and the fruits of their labours, of course. As an orchardist I will call Joanne ${ }^{3}$ (of Banfield Community Orchard) explained, "We all planted it. We all work in it. We all harvest it, and it's not always the same people, the same time. And we share. Sharing is the big thing."

Like community gardens, community orchards have many functions and even more meanings. They are at once a form of urban agriculture, a claim to public space, a site of therapeutic recreation, socialization, and beautification; and, at least for some participants, a demonstration of radical democratic potential and environmentalist, socialist, and/or anarchist ideals. I have come to understand community orchards as forms of political gardening (Certomá \& Tornaghi, 2015) through which participants seek to bring about social change. Specifically, I

\footnotetext{
${ }^{3}$ Hereafter, interviewees I quote will be introduced by name (pseudonym) followed by the (shortened) name of the community orchard with which they are affiliated.
} 
see community orchards as experiments in reclaiming the commons - those natural and cultural resources (or gifts) we inherit (or create) and collectively enjoy, to which we all have access, and for which we share a responsibility to maintain and hold in trust for future generations (Barnes, 2006; Quilligan, 2012).

Table 1: Community Orchards by Physical \& Organizational Characteristics

\begin{tabular}{|c|c|c|c|}
\hline $\begin{array}{l}\text { Orchard (Year of } \\
\text { inception) }\end{array}$ & Location (size) & Leaseholder & Varieties grown \\
\hline $\begin{array}{l}\text { Copley Community } \\
\text { Orchard (2011) }\end{array}$ & $\begin{array}{l}3590 \text { Copley St., } \\
\text { Vancouver (1.2) } \\
\text { acres) }\end{array}$ & $\begin{array}{l}\text { Environmental Youth } \\
\text { Alliance (to 2016); Copley } \\
\text { Community Orchard } \\
\text { Society (as of 2017) }\end{array}$ & $\begin{array}{l}\text { apples, cherries, pears, plums, walnuts and figs, } \\
\text { as well as strawberries, raspberries, blueberries, } \\
\text { currants, honeyberry, jujubes and kiwi vines }\end{array}$ \\
\hline $\begin{array}{l}\text { Strathcona } \\
\text { Community } \\
\text { Gardens (1985) }\end{array}$ & $\begin{array}{l}857 \text { Malkin Ave., } \\
\text { Vancouver ( } 1 \text { acre) }\end{array}$ & $\begin{array}{l}\text { Strathcona Community } \\
\text { Gardens Society }\end{array}$ & $\begin{array}{l}\text { Over } 130 \text { varieties of apple and } 14 \text { varieties of } \\
\text { pear; plus walnut, persimmon, plum, cherry, } \\
\text { paw-paw, Asian pear, peach, olive, sea berry, } \\
\text { nectarine, Chinese date, salmonberry, fig, } \\
\text { currant, mulberry, goumi, quince, crabapple, } \\
\text { hazelnut, grape, loquat, chestnut, boysenberry }\end{array}$ \\
\hline $\begin{array}{l}\text { Jonathan Rogers } \\
\text { Park (2010) }\end{array}$ & $\begin{array}{l}110 \text { West } 7^{\text {th }} \text { Ave, } \\
\text { Vancouver (n/a*) }\end{array}$ & $\begin{array}{l}\text { Elizabeth Rogers } \\
\text { Community Gardens }\end{array}$ & Apple, plum, and pear \\
\hline $\begin{array}{l}\text { Norquay Learning } \\
\text { Orchard (2006) }\end{array}$ & $\begin{array}{l}2732 \text { Horley St., } \\
\text { Vancouver ( } 0.14 \text { acre) }\end{array}$ & $\begin{array}{l}\text { Renfrew-Collingwood Food } \\
\text { Security Institute }\end{array}$ & $\begin{array}{l}2 \text { heritage varieties of apple, } 5 \text { varieties of pear, } \\
2 \text { plum, cherry, blackberry, laurel, fig, blueberry, } \\
\text { kiwi, kiwiberry, read and white grapes, black and } \\
\text { white currants, and a dozen varieties of edible } \\
\text { berries native to Western Canada }\end{array}$ \\
\hline $\begin{array}{l}\text { Spring Ridge } \\
\text { Commons (1999) }\end{array}$ & $\begin{array}{l}\text { Corner of Chambers } \\
\text { ST. \& Gladstone Ave., } \\
\text { Victoria ( } 0.5 \text { acre) }\end{array}$ & $\begin{array}{l}\text { Fernwood Neighbourhood } \\
\text { Resource Group }\end{array}$ & $\begin{array}{l}\text { Apple, pear, figs, buckthorn, goumi berries, } \\
\text { mulberries, goji berries, kale, arugula, lima } \\
\text { beans, herbs, miners' lettuce }\end{array}$ \\
\hline Banfield Park (2013) & $\begin{array}{l}521 \text { Craigflower Road, } \\
\text { Victoria ( } 0.04 \text { acre) }\end{array}$ & $\begin{array}{l}\text { Vic West Food Security } \\
\text { Collective }\end{array}$ & $\begin{array}{l}\text { Apples (about half of total), figs, mulberries, } \\
\text { plum, pear, nuts }\end{array}$ \\
\hline $\begin{array}{l}\text { Fernwood } \\
\text { Community } \\
\text { Orchard (2013) } \\
\end{array}$ & $\begin{array}{l}1240 \text { Gladstone Ave., } \\
\text { Victoria ( } 0.12 \text { acre) }\end{array}$ & $\begin{array}{l}\text { Fernwood Neighbourhood } \\
\text { Resource Group }\end{array}$ & Fruit and nuts \\
\hline $\begin{array}{l}\text { Welland Legacy } \\
\text { Park (2013) }\end{array}$ & $\begin{array}{l}1215 \text { Stancil Lane, } \\
\text { View Royal ( } 0.75 \\
\text { acre) }\end{array}$ & LifeCycles & $\begin{array}{l}\text { Over } 100 \text { varieties of heritage apples as well as a } \\
\text { selection of: pears, plums, figs, paw-paw, } \\
\text { hazelnut, medlar, quince, cherry, grapes, kiwi, } \\
\text { persimmon }\end{array}$ \\
\hline $\begin{array}{l}\text { Ben Nobleman } \\
\text { Orchard (2009) }\end{array}$ & $\begin{array}{l}1075 \text { Eglinton Ave., } \\
\text { West Toronto (n/a*) }\end{array}$ & Informal & $\begin{array}{l}\text { Apples, plums, apricot, sweet cherries, paw-paw, } \\
\text { Asian pear }\end{array}$ \\
\hline
\end{tabular}

*Size is not applicable to trees planted within City parks because the area is not simply an orchard; the fruit trees are part of multi-functional space and it is not meaningful to calculate what proportion of the area of the park they occupy. 
The commons represent a realm outside of both market and state, in which members of civil society engage in collective self-governance around the management of a shared resource or space. The goal is to protect and enable the access of all community members to basic life goods (Johnston, 2003; Linebaugh, 2009), life goods being distinguished from commodities on the basis of two criteria: 1) freedom from price barrier (while markets can be used for distribution, these goods cannot be restricted to those with resources), and 2) the property of enabling vital life-capabilities (McMurtry, 2001, p. 827, 837). In other words, commons typically operate outside systems of commodification. They express a social order based on cooperation and reciprocity, not competition, where the borders between particular and collective interest(s) are blurred and fluid (Bollier, 2012). Consequently, it is helpful to think of commons as relations more than things (Huron, 2015). ${ }^{4}$

Commodification vs. the Gift in Community Orchards

Commodification involves the transformation of goods, services, ideas, and people into objects to be bought and sold. A commodity can be thought of as "anything intended for exchange" (Appadurai, 2005, p. 35); its exchange value is prized over its use value. A decommodified space is therefore one in which goods, services, ideas and people (through their labour) are not exchanged for money (if they are exchanged at all), but instead are freely given. Community orchards are easily recognized as decommodified spaces insofar as they are spaces characterized by creation, production, and regeneration, not purchase or sale. In a broader sense as well, as they are decommodified spaces insofar as access and belonging are not dependent upon a person's ability to purchase or consume. Instead, interactions in the garden are predicated on a social and economic practice Crouch and Ward (1988) term "the gift relationship". This relationship owes itself in part to the fact that community gardeners are typically prohibited from selling their produce (City of Victoria, 2016; McKay, 2011). ${ }^{5}$ Consequently, gardeners tend to share their surplus produce with each other and also just give it away (e.g., by donating it to a food bank).

\footnotetext{
${ }^{4}$ I acknowledge that there is a risk that the term 'commons', being associated with English history, might seem a colonial one, and even come across as tone-deaf in this day and age. We need to openly discuss whether or not the concept is compatible with decolonization imperatives. I believe that the concept of the commons is very much in keeping with Indigenous orientations to land, and agree with Sharma \& Wright who argue for an understanding of colonialism as the theft of the commons (other people's commons) and decolonization as a struggle against historical relations of expropriation and exploitation, leading to the gaining of a global commons (2008-9, p. 132-3).

${ }^{5}$ Interestingly, this characteristic does not seem to be shared with community orchards in the UK, where selling the produce - as well as value-added items such as jams, jellies, pies, and ciders - is encouraged, through green grocers, farmers' markets, and road-side stands (King \& Clifford, 2011).
} 
It is this idea of the gift that provides a tangible counterpoint to the commodity. Consequently, if we are to really understand decommodification, we need to understand gift theory. Here, I turn to the work of Lewis Hyde, whose 1983 book, The Gift, counter-posed the selflessness of creative works to the culture of capitalism and offered a mediation on what it means to be an artist in the modern world (Hyde, 2007). It is following Hyde's work that Crouch and Ward (1988) made their oft-quoted observation that social and economic behaviour in UK allotment gardens is predicated on the "gift relationship"-i.e., sharing of produce, mutual aid, and a general refusal to exchange produce for money. ${ }^{6}$ Hyde's book has come to be regarded as a modern classic and a touchstone for understanding the workings of gift economies generally.

According to Hyde, the difference between a gift and a commodity is profound. The gift is offered freely, with no expectation of return to the giver; it functions to establish a feelingbond between people. Gifts function as covenants, symbolizing an understanding and a desire regarding relationship. This is most evident in gifts of incorporation (as in wedding rings), gifts of peace (to abolish division), and gifts of atonement (to re-establish broken bonds). Sometimes gift exchange is circular, meaning that the giver gives to someone from whom they will not receive, though they will eventually receive from someone else. In large groups, gifts act not so much to consolidate bonds of affection between individuals as to constitute and affirm group membership — to make one body out of many (Hyde, 2007, p. 97). In community orchard and community garden circles, this is evident in the long-established ritual of the potluck (de rigeur after a work party) where labourers come together and share the edible gifts each has brought to the community table. Gifts bring with them a sense of cohesion, providing "a kind of anarchist stability"; gifts act to make one body out of many (Hyde, 2007, p. 97).

The commodity, on the other hand, is exchanged either for money or for an equivalently valued trade item; the exchange leaves no lasting connection between the individuals involved. In other words, a commodity becomes a commodity by moving between two separate spheres without abolishing their separation. For that reason, says Hyde, "we do not deal in commodities when we wish to initiate or preserve ties of affection" (2007, p. 85). Writes Hyde,

Because of the bonding power of gifts and the detached nature of commodity exchange, gifts have become associated with community and with being obliged to others, while commodities are associated with alienation and freedom. (2007, p. 85-86)

The freedom of commodity exchange has to do with the lack of any lasting obligations between people that are created as a result. Commodity exchange is concerned only with paying to balance the scale. Gift exchange, on the other hand, creates an obligation, not necessarily to

\footnotetext{
${ }^{6}$ Hyde's work was in turn based on that of anthropologist Marcel Mauss, whose influential book, The Gift: The form and reason for exchange in archaic societies, was originally penned in French in 1923 and first translated into English in 1954 (Mauss, 1923-24 as cited in Hyde, 2007).
} 
return the gift directly, but more often to pay it forward, producing a sense of momentum, of weight shifting from body to body so as to keep the gift in motion. (Hyde, 2007, p.11).

For these reasons, when a thing - be it fruit, labour, service, or idea - is not bought but received; not sold but given, the consequences can be profound. From my interviews with community orchardists, I learned that the ethos of the gift changes the ways orchardists view the fruit they produce, the land they work, and the other elements of nature that support the orchard; as well as their own labour, and their relationships to each other and to those to whom they offer their gifts.

\section{Fruit as gift}

Community orchardists tend to view the fruit trees as gifts, not resources or commodities. The apples, cherries and quinces are gifts of nature; so are the bees, and the pollination services they perform. This point was made clear to me when I asked interviewees how they would feel about selling the fruit that the question was simply a non-starter. Some interviewees did float ideas like selling tree cuttings or value-added fruit products (e.g., jam) to help sustain their projects, but all seemed to reject the model of producing the fruit itself for profit. Said Ariel (Copley),

I don't like that idea. I don't see it that way... If the members can sell the fruit, then why can't somebody else take the fruit and sell it? In a way, it just introduces the notion of commodifying property... We communally own [it, but] not so much in the commodified sense. We "own" it in that we're responsible to it, but not in that we get to sell it.

Ariel's idea of communally owning as being responsible to something is significant. Orchardists recognize that gifts of fruit come through their labours (insofar as they assist nature), but these gifts don't belong to them. Consequently, Ariel rejects selling the fruit for profit, and wants instead to give it away. In the words of Lewis Hyde, such a view "makes evident the true structure of our relationship to the sources of our wealth... To accept the fruits of these things as gifts is to acknowledge that we are not their owners or masters, that we are, if anything, their servants, their ministers" (2007, p. 191). Such a view is clearly more aligned with a stewardship ethic than is a view of fruit (or nature) as property. In this way, the idea of the gift may be one key to the paradigm shift that long-term sustainability requires.

Because they see the fruit as a gift of nature, community orchardists are less inclined to feel proprietary about it. If they do not own it, the labour they contribute to maintaining it must be regarded as a gift to beneficiaries whom they may never see. As Gwynne (Spring Ridge Commons) put it,

When you grow food here it's with the understanding that you may not be harvesting it, somebody else might. So, it's sort of gift giving, in that it's like Christmas or a potlatch or 
something like that, where the emphasis is on the giving, and so much abundance is generated out of that.

This idea that abundance is generated from giving is a point that Hyde makes too. He uses the example of creative gifts, noting that we frequently speak of talent as a gift.

To have painted a painting does not empty the vessel out of which the paintings come.

On the contrary, it is the talent which is not in use that is lost or atrophies, and to bestow one of our creations is the surest way to invoke the next. (2007, p. 189)

The paradox of the gift is that it is use that ensures plenty:

Gifts are a class of property whose value lies only in their use and which literally cease to exist as gifts if they are not constantly consumed... What is given away feeds again and again, while what is kept feeds only once and leaves us hungry (Hyde, 2007, p. 26).

Thus, the concept of the gift has the potential to profoundly challenge deep-seated notions of scarcity in capitalist societies. But it's not an easy challenge to embrace, either for orchardists or for the general public. Most community orchards are located in public spacesmany of them city parks — open to everyone. Challenges arise, however, when others do not understand or respect the orchardists' view of the fruit as a gift for sharing. Of course, orchardists recognize that because they do not own the land, nor control access to it, they cannot claim exclusive rights to the fruits produced within the orchard, either legally or morally. But nor do they want to. In these orchards, the long-term vision has always been an enlarged circle of abundance and sharing ${ }^{7}$. Says Yuki (Copley), "The intention really is to make [the orchard] a community resource." Community orchardists do this by inviting the general public to join in on work parties, and to help themselves to fruit when it is ripe. They also host community foodsharing events like harvest parties, cider-making, even a traditional wassail at Banfield, in Victoria. Consequently, most orchardists aren't comfortable characterizing over-taking by the public as theft. But they do experience distress when members of the public take fruit in ways other than those intended. I believe this is because doing so violates the spirit of the gift, in at least three distinct ways.

\footnotetext{
${ }^{7}$ Orchards that are inside community gardens are different because community gardens operate on a clear membership basis, meaning that the fruit should, by rights, accrue just to members, rather than the broader community. Here, the experience of having large amounts of fruit taken can produce sharp divisions among members. Some desire not to be insular or exclusive, like a club, and express resignation about their losses. Others, who regard their garden plots or the orchard as a form of (pseudo) private property, are "up in arms about it, to the point of wanting to take photographs of perpetrators and post them" (Cecilia, Strathcona).
} 
First, orchardists can become frustrated with people who take fruit before it is ripe, and/or who take a bite and then throw it on the ground. Not only is this wasteful, it also thwarts the givers' intentions, depriving them of the fulfillment of giving a fully-formed gift that will offer pleasure to its recipient. As one orchardist lamented, "If only that person had waited until the fig was ripe, they would have discovered how incredible a ripe fig tastes!" In the scenario in which people take too much fruit, the giving is undermined in a different way. Ideally, when one gives, one does so knowingly and deliberately; giving is a choice made by the giver, even if the recipients of one's gift remain largely unknown. It is a very different matter when all the cherries are raked from your trees the night before a planned harvest celebration (as happened at Ben Nobleman Community Orchard in Toronto). It is not just the fruit but the givers' agency that has been stolen. And when community orchardists imagine that someone might be taking the fruit to sell, the disappointment is profound because such acts represent a violation of this understanding of the fruit as a gift - an understanding the orchardists had hoped would be shared. Turning the fruit into a commodity profoundly alters the meaning of their labour and the phenomenon with which they are engaged, or wish to be.

Second, more than the loss of the fruit, what community orchardists seem most disappointed about is the lack of consideration such acts show for others; theft is wrong because it denies others their gifts, effectively excluding them from the circle.

The third problem is that people who take but don't work to maintain the orchard aren't contributing gifts of their own. This is known in the commons literature as the "free-rider" problem. This may be the hardest problem to solve, especially for community orchards that are located within public parks. As a commons, especially one characterized by a gift economy, a community orchard needs clear boundaries to establish where and for whom its norms apply. ${ }^{8}$ Yet a public park is, by definition, open-access - not bounded at all, but contiguous with the social and economic space that makes up the rest of the city, in which decidedly different norms prevail. Taking from the commons without contributing in some way represents a third kind of violation of the spirit of the gift — a failure to reciprocate and help keep the gift in motion.

\section{Labour as gift}

"Labor should not be sold like merchandise but offered as a gift to the community" - Che Guevara (as cited in Hyde, 2007, p. 87)

Community orchardists are engaged in reciprocal giving with nature when they offer the gifts of their own labours and time. Shannon (Ben Nobleman) described "the deal" between the orchard stewards and the trees this way: "We will care for them and they will give us great fruit, but if

\footnotetext{
${ }^{8}$ Clear boundaries - around both the resource and the community of commoners - is the first and most important principle for ensuring the sustainability of a workable commons, one of eight originally identified by Elinor Ostrom (1990) and later corroborated by extensive transdisciplinary research.
} 
we don't care for them, they will give us crappy fruit or none at all." Orchardists like Shannon give of their own labour not only to produce fruit, but also to cultivate relationship with the trees. This is evident in the way she speaks about pruning:

It's the most special time. It's when you create a relationship with your tree... if you're pruning correctly...It's not just hacking limbs off. The tree, with its buds, sort of shows you where it needs to be cut...You watch how the tree works with you. It's a very beautiful time.

Giving of one's labour creates a relationship not just to one or more living things, but to natural cycles. As Lewis Hyde writes, "[T] he circle of gifts enters the cycles of nature and, in so doing, manages not to interrupt them and not to put man [sic] on the outside" (2007, p. 23-24). Labour as relationship-building thus acts to heal the alienation that characterizes dominant agroindustrial food systems, and to which many interviewees referred. ${ }^{9}$

Giving of one's labour also builds relationship with others in the community. Community orchardists devote countless hours to their projects and make the orchards a very significant focus of their lives, sometimes for years on end. In this way, spearheading a significant transformation of a public space is like giving a gift to the whole community. Orchardists labour to give the gift of knowledge — particularly to neighbourhood children, who will benefit from seeing how food grows and tasting it right off the tree-and the gift of enjoyment that others will get out of being in an improved space where they interact in beautiful ways. Miles (Copley) spoke of "removing [food] from this commodity-based economic system and putting it into more of a social, community-based context", observing that

It has a different meaning. It has a different feeling to it, too. It's nourishing both for you individually, and your health, but it also nourishes the spiritual and social side of us that commodity agriculture-industrial food system doesn't nourish in the same way.

Orchardists gift their labour to planning, organizing, tending, and problem-solving when things go sideways - as when irrigation lines or standpipes break and it is up to the orchardists to fix them. Because the orchardists feel it is their project, their "baby", they are motivated to contribute. Tim (Welland) exemplified this spirit of giving when he said, "Ask not what the orchard can do for me; ask what I can do for the orchard." In fact, though, gifts are never unidirectional. As Walt Whitman famously observed, "The gift is to the giver, and comes back most to him - it cannot fail..." (as cited in Hyde, 2007, p.13). Hyde describes gifts as "an emanation of Eros" (2007, p. 357), understood in the Jungian sense of a desire for connection

\footnotetext{
${ }^{9}$ Alienation is, of course, a well-known Marxian concept pertaining to labour under capitalism. In the food realm, McClintock (2010) conceptualizes alienation as one of three dimensions of "metabolic rift" the ecological, the social, and the individual - that have come about because of the industrialization of agriculture under capitalism.
} 
and wholeness, in contrast with Logos, which is associated with objectivity and rational calculation. This sense of connection and wholeness is deeply satisfying, such that there may be no other return necessary for the giver; the act of giving is self-reciprocating.

Again, the theory fits what I observed. When asked about what motivates them to contribute to community orchards, interviewees sometimes mentioned therapeutic benefits such as relaxation and enhanced mental health, and a sense of connection with others. But more often they talked about the rewards of giving itself. Said Dorothy (Welland), "It's so fulfilling, absolutely so fulfilling. I look forward to it. I had to miss one day and it was... It didn't feel right!" As Dorothy's fellow orchardist, Jake, observed,

It's almost like when you work. If you just work for a pay cheque, the extrinsic rewards, then the job isn't that important. But with the intrinsic rewards and self-fulfillment and community contribution, then it becomes a lot more valuable. That's what Welland Park is providing for us. It's a really great place to be.

Perhaps no quote better exemplifies Whitman's idea that the gift is to the giver than this one from Gwynne (Spring Ridge Commons):

It's not necessarily me giving, I am being given to at the same time...I am not thinking, 'Oh, I am giving this to this person'. It's like I am receiving. I always feel that it's a privilege.

The desire on the part of community orchardists to give of themselves is also in large part a response to the gifts they have received from those who came before, and from each other. At Welland, orchardists frequently refer to the altruistic efforts of the orchard's namesake, Rex Welland, whose generosity and public spiritedness continue to inspire others to give of themselves for the community. Jasmine (Welland) reflected on Rex's contribution with awe, "Somebody, not that different from you and me, did this, in their retirement, in their spare time, and look at how it's transforming this community!" Orchardists also see the voluntary labour of their fellow workers as a gift that contributes to realizing the vision community orchardists share. And at Toronto's Ben Nobleman, there is evidence that the work of the orchardists and their enthusiasm for improving their park has influenced City workers, who, in response, have gone above and beyond, giving gifts of their own to support the orchardists' efforts to improve the park. Shannon outlines this dynamic as she has experienced it:

Parks and Rec, when they know how much we care about our park, I think they spend more time there. And if I have a problem, I can call the head gardener of our area, and he's so happy to come out and help us out...because he knows that we care. 
There is an infectiousness to the gift - the way it inspires others to give in kind, producing that sense of momentum or weight-shift from body to body that keeps the gift in motion.

That is not to deny the difficulties many community orchardists experience in getting others on-side with such a radical vision, or in ensuring that work is shared equitably within the community orchard. There are invariably leaders, or super-volunteers, who do immense amounts of work because they make the orchard their passion; they give of themselves selflessly to benefit others whom they may never meet, hoping fervently that others will continue to join in, to give, to show up, to stay with the project, to follow through on what they said they'd do. As Joanne (Banfield) candidly observes,

It's exhausting. And we've gone through these things where we're like 'To hell with it. I just can't do it. I'm tired of asking and being the only one.' And then something amazing happens, like ten people turn up, absolutely bizarrely, and you're just filled with this energy that takes you a little bit further...

That organizers like Joanne can be re-energized in this way suggests that it is not just the labour itself, but the reciprocity (or lack thereof) that makes the difference between continuing and burning out. When orchardists feel that others are keeping the gift in motion, they are motivated to continue, even when the work is hard, as it often is. Hyde writes, "When the gift passes out of sight and then returns, we are enlivened...each gift is an act of social faith" (2007, p. 20).

One challenge that follows from conceptualizing labour as gift is that those who volunteer their labours typically want to give their time and efforts freely, without coercion. To some, this can mean a desire for very little structure or rules-e.g., regarding commitments to work parties — which can pose difficulties for grassroots organizations working in the social economy. These difficulties may well be unavoidable in decommodified spaces governed by the ethos of the gift, but understanding the theory behind why this is so may help to manage expectations.

According to Hyde, the gift economy is governed by two ethical directives: 1) that each participant should determine their own contribution within vaguely specified expectations; and 2) that the equivalence of two persons' contributions is not to be discussed. Instead, the equivalence of the counter-gift is left to the giver. Consistent with this ethos, community orchardists I spoke with described their work as wholly voluntary, and frequently expressed how much they enjoy freely giving of their time. Gwynne (Spring Ridge Commons) commented,

You're working in a way that isn't bound in the same way that other work is. In volunteering your work, it's like you still own your labour, right? It's the difference between work that is done for remuneration or that becomes a kind of slave labour, 'cause that's labour that's being taken from you. This is labour that you give but you're getting so much in return. It gives it a certain power when you give your labour freely... labour is the only thing that you actually possess as a poor person. 
Of course, it is a privilege to be able to choose to give freely of one's time; not everyone can do that. As Allen points out, "those with the greatest need often have the least ability to exercise individual choice" precisely because "allocations of choices are shaped by the historical demographics of inequality" (2010, p. 300). Indeed, many authors have voiced important critiques of volunteerism, saying that it may also promote conditional citizenship (Lepofsky \& Fraser, 2003; Perkins, 2010), and "discipline citizens to accommodate rather than confront the state" (Ghose \& Pettygrove, 2014, p. 1107). Rosol (2011 and 2018) also articulates critical debates around volunteering and neoliberal municipal land management; admittedly, the line that separates community empowerment and cooptation by the state may indeed be a fine one (Perkins, 2009, 2010; Rosol, 2010). At the same time, I would assert that there is a world of difference between the City conscripting volunteers to do the City's work for them and the phenomenon of community orchards, which are grassroots-driven and in fact making demands of the state (for access to vacant land, for materials, for funding etc.) — not the other way around.

The larger point here is not that food production by unpaid volunteers represents an ideal or a panacea, but that decommodification of food entails changes above and beyond the way we approach exchange, and that any effort to sketch out workable food-as-commons models will need to appreciate the ways that labour, motivation, reward, and social relationships may also need to be reconceived in a system founded on decommodification.

Community orchardists also told me that having the autonomy to be able to determine the nature and extent of their own contribution is very important to them. Said Bill, of his extensive work championing and supporting native pollinators at Welland Community Orchard,

I'm 80 years old and I want to do my thing when I want to do it. And this fits in perfectly. I enjoy doing this...but nobody puts any pressure on me. I don't come to many of their Sunday pruning gatherings...but they just leave me alone to do my thing, because they know I'm doing it.

Successful community orchard leaders and initiators understand the importance of allowing volunteers the freedom to choose how and when to labour in the orchard, and they respect it. As Zsófia (Ben Nobleman) explained,

It's never like, 'You didn't come last time. I was looking for you!' When you give people a choice - you can come or not - people choose to go. But if they tell you to go, you'll be like, 'I'm not going!' It takes away your freedom.

Interviewees also indicated that when the giving is free and not at all coerced or imposed, people often do much more than they need to. Carolina (Strathcona) gave a good example: 
We have a gardener who goes to church every Sunday so he doesn't come to work parties but he's here at least three times a week and he does all the mowing of the grass and cuts stuff. And he paints tables and uses his own money.

From these quotes, it seems that it is not obligation per se that people chafe at, but imposition. In a gift economy, the obligation to give, and to reciprocate, is understood and accepted. When people feel an obligation to the orchard and to each other that arises from within, it compels them to give in ways they typically feel good about. But when the shape, form, timing, quantity, or value of the gift is externally dictated, or seems to come from "above", people will tend to resist.

The second ethical directive in a gift economy, as mentioned above, is that the equivalence of two persons' contributions is not to be discussed. I found this to be very true in that community orchardists seemed very reticent to link the amount of work done to any worker's entitlement to a particular quantity of fruits, or proportion of the harvest. The reasons for de-linking inputs and outputs are many and include, admittedly, the difficulty of quantifying, measuring and monitoring members' labour, as well as the acknowledgement that each member brings different abilities to contribute. Some who are older or physically less fit may not be able to contribute in ways that require heavy lifting or bending over or sustained vigorous activity, while some who have young children might be time-strapped and unable to consistently show up as planned. Instead, the ethos in the community orchard tends more towards Marx's oft-quoted maxim, from each according to ability and to each according to need. This, too, illustrates the gift orientation of community orchardists. When asked his views on correlating orchardists' hours worked to numbers of apples or other fruit they might take home, John (Strathcona) said, "I don't know if anybody'd really be too keen on that. It would be like commodification."

The avoidance of equivalences can also be traced to the effects this might have on relationships within the orchard. Specifically, the lack of trust that is suggested by any members' felt need to measure and monitor others tends to work against the establishment or nurturance of social bonds. As Hyde says, "emotional connection tends to preclude quantitative evaluation" (2007, p. 85). And for those who understand themselves to be engaging in a gift economy, and who see their labour as a gift, the very idea of measurement is alienating and de-motivating. Community orchardists understand intuitively what Hyde meant when he wrote that "[W]ealth ceases to move freely when all things are counted and priced." (Hyde, 2007, p. 28). Most of the time, members are entrusted to be self-monitoring and to do their part with little, if any, external verification. That is not to say that it always works, just that autonomy and self-direction (with loose oversight) seems to bring out the greatest commitment and initiative in members. 
To summarize, I've asserted that interactions in community orchards are predicated on the gift relationship. This includes interactions between orchardists and the trees (land, soil, pollinators, nature...) as well as interactions among orchardists and between orchardists and the public. The gift relationship shapes and informs the way community orchardists feel about the space, the fruit, and the ways they give of themselves to make both available to others. This gift orientation is evidenced in the resistance interviewees feel toward commodification, in the nature of the joys and disappointments they report, and in the conditions under which they offer their labour. Specifically, they take joy in building relationships, both with the trees and with their fellow orchardists; in connecting with the seasons, the pollinators, and the soil; and in giving of themselves in ways that generate intrinsic rewards. They feel disappointment when others do not understand the nature of the gift, or violate it in spirit by taking too much, by wasting fruit, or by turning fruit into a commodity.

Naturally, questions arise about the sustainability of these projects long-term. Community orchards have very porous boundaries, both spatially and socially, which can make them harder to maintain ${ }^{10}$; turnover in some community orchards is high; organizationally, many are fragile. At most community orchards, distribution of the harvest is not highly organized, and the harvest itself is almost impossible to monitor. As these are public spaces, open to everyone, it is nigh impossible to know to whom orchardists are ultimately giving their efforts, and the fruit. Beyond the sharing they do together in harvest parties, beyond distribution within their own selforganized groups, the beneficiaries may be unknown. Certainly, there are countless anonymous passers-by who benefit from a piece of fruit here or there (or sometimes, quite a lot of fruit). In most community orchards, this is all part of the design and the orchardists' shared vision. It is therefore quite difficult to evaluate how equitable the end result may be. Still, community orchards represent something all too rare and in need of promotion: a living, working manifestation of the belief that food can be conceived of as a public good, and a demonstration of what Stavros Stavrides calls "the emancipatory potentialities of sharing" (2016, p. 74).

What, then, can we learn from community orchards and/or from gift theory that might be of value to the development of novel models of food production that might one day actualize decommodification on a larger scale? One take-away might be simply that it is important to think of what a space (or model or system) is, instead of just what it is not. The term "decommodified" tells us only that goods, services, idea and people's labour are not being bought and sold. If we accept Hyde's premise that the opposite of the commodity is the gift, then we have something more constructive to work with-namely, the question of how to promote giving.

\footnotetext{
${ }^{10}$ On the other hand, porous boundaries can help ensure that commons do not become new forms of enclosure. The concept of porosity and "expanding commoning" is promoted by Stavrides as "a step towards a culture of mutual involvement and negotiation" (2016, p. 72).
} 
Some might be tempted to think of other ways to use money as an enticement to people to give or volunteer more. But as Michael Carolan (2017) reports, the introduction of money into charitable initiatives is well known to deter and reduce giving. Economists call it the "crowdingout effect" whereby intrinsic motivations are crowded out by external rewards (2017, p. 111). As far back as the 1970s, researchers looking at the phenomenon of blood donation were reporting that programs that paid people a nominal sum to donate actually had lower rates of participation (Carolan, 2017, p. 111). Offering financial compensation changed the meaning of the donation from being a selfless act to one motivated by self-interest; their donation was no longer a gift. This suggests that the absence of money is an important part of what brings people together in mutual aid, in a spirit of generosity, and with feelings of commonality.

Moreover, community orchards show us that a decommodified space is not just a space marked by an absence of monetary transactions, but one in which even the notion of equivalence in exchange is challenged. A de-commodified space is one that evinces a sense of obligation to give or reciprocate that arises from within rather than being imposed from without. A decommodified space is one in which volunteering is so much more than doing unpaid work; the voluntariness of it is paramount-i.e., the autonomy, the agency, the gift. This understanding is especially important when we consider that many community orchardists are driven to heal a sense of alienation they feel from the land; labour can only be thought of as de-alienating to the extent to which it is freely given. ${ }^{11}$

In sum, if we want to promote a gift economy, we need to trust in the different logic and ethos that guides it. I have suggested that this more helpful ethos may be one that promotes autonomy, non-coercion, and the sense of belonging that generates an intrinsic felt obligation to accept and to keep the gift in motion. It is an ethos that reflects very different conceptions of scarcity and abundance. Hyde quotes the anthropologist Marshall Sahlins, who famously claimed that hunters and gatherers "have affluent economies, their absolute poverty notwithstanding." This is because they do not arrange production and distribution through the behaviour of prices, nor allow an "insufficiency of material means [to] become the explicit, calculable starting point of all economic activity" (Sahlins as cited in Hyde, 2007, p. 28). Following both Sahlins and Hyde, we can see that the gift economy is in fact a rebellion against scarcity, or its centrality as an organizing principle in modern economies: "In the world of gift...you not only can have your

\footnotetext{
${ }^{11}$ That said, I want to acknowledge that there are many who work the land in ways that are healing and not completely outside of a cash economy, Community-Supported Agriculture (CSA) being one of them. I would suggest that insofar as ethical and sustainable farmers are rarely compensated adequately for what they do, and are instead driven by higher ideals, many are already engaging in the spirit of the gift (and sacrifice). Also, in the case of CSA's, we can see aspects of decommodification in the de-linking of precise volume/quantity of produce and money, and in the non-monetary forms of reciprocity involved: consumers give the farmers a gift of trust and risk-mitigation, and the farmers give the consumers not only healthy food but assurances that their social, environmental and spiritual values are being upheld.
} 
cake and eat it too, you can't have your cake unless you eat it." (Hyde, 2007, p. 27). Where use assures plenty, and to possess is to give, new ways of seeing and sharing open up to ensure the continuation of "this abundance that we share" (Gwynne, Spring Ridge Commons).

But surely I am not saying that all food provision can be organized this way - produced by volunteers and given away for free? I am not. We all know that there are realms of human need that are not well supported in a market-centred economy. And as a society, we do sometimes find non-market ways to organize around the provision of things we value-if we value them enough. I see in the efforts of community orchardists, and in the broader social economy, a recognition that food may fall in this category, and a desire to organize in nonmarket ways around its provision. However, there are limits of scale when it comes to gift economies. Moreover, it is evident that those who produce food have expenses that must be paid in cash and that they need to make a living. Even voluntary organizations need financial support. Consequently, some degree of gift and commodity co-existence must be expected in even the most progressive food systems.

Still, I take the existence of community orchards as a sign that at least some among us are starting to point in the direction of food as a commons more generally, even if the eventual shape of such a thing might exist only in embryonic form today. Markets are ubiquitous in our lives and will undoubtedly be for some time to come, but non-commodified spaces like community orchards, where the gift relationship predominates, signal a hopeful opening of our collective imagination to the potential for something radically different to emerge.

While there are many facets of community orchards that could be discussed in relation to the social economy of food-including their contributions to multi-functionality and participatory democracy in food systems; the increased opportunities they represent for collective action and collaboration; and their relationship to post-neoliberalism - in this article, I have focused on decommodification because I think it represents a sort of "holy grail" in critical food scholarship, a quality that many scholars have suggested aspiring to, but that still largely eludes understanding, given the paucity of operational models available for emulating. There are many steps yet to be imagined in order to scaffold new, more just and sustainable (and scaledup) models of food production onto what currently exists. But if this description of the gift economy in community orchards can spark some new ideas or fertilize others' thinking about the place of decommodification in the social economy of food, I would be most content to set that gift in motion.

Acknowledgements: This research was supported by the Canadian Social Sciences and Humanities Research Council (SSHRC) and Carleton University (Ottawa). The author gratefully acknowledges the contributions of all those interviewed, and the helpful constructive insights provided by Dr. Trish Ballamingie, Dr. Charles Levkoe, and Dr. Irena Knezevic, as well as those of two anonymous reviewers. Any errors and misinterpretations are mine alone. 
References

Alkon, A.H., \& Mares, T. (2012). Food sovereignty in US food movements: Radical visions and neo-liberal constraints. Agriculture and Human Values, 29(3), 347-359.

Allen, E. (2010). Growing community food systems. In R. Heinberg, \& D. Lerch (Eds.). The Post Carbon Reader: Managing the $21^{\text {st }}$ Century's Sustainability. Post Carbon Institute. Retrieved from http://library.uniteddiversity.coop/Cooperatives/Food/ Growing_Community_Food_Systems-Post_Carbon_Reader.pdf

Ames, G.K. (2013). Community orchards. National Sustainable Agriculture Information Service (ATTRA). Retrieved from http://www.attra.ncat.org.

Appadurai, A. (2005). Definitions: Commodity and commodification. In M. Ertman, \& J. C. Williams (Eds.), Rethinking commodification: Cases and readings in law and culture (p. 35). New York: University Press.

Barnes, P. (2006). Capitalism 3.0: A guide to reclaiming the commons. San Francisco: BerrettKoehler Publishers.

Barron, J. (2018). The giving trees: Community orchards as new urban commons. (Doctoral dissertation). Carleton University. Ottawa, Canada. Retrieved from https://curve.carleton.ca/fa95641c-0825-4724-a3a7-6e75d0ddb926.

Baxter, J. (2010). Case studies in qualitative research. In I. Hay (Ed.), Qualitative Research Methods in Human Geography (3 ${ }^{\text {rd }}$ ed.) (pp. 81-97). Oxford University Press: Don Mills.

Betz, M. (2014). Governance of community orchards: A case study (Unpublished graduate paper written for Y673 Seminar, The Vincent and Elinor Ostrom Workshop in Political Theory and Policy Analysis). Indiana University, Bloomington, IN.

Bollier, D. (2012, June 5). The commons emerges as a theme at the People's Summit in Rio [Blog post]. Retrieved from http://bollier.org/blog/commons-emerges-themepeople\%E2\%80\%99s-summit-rio.

Bollier D., \& Helfrich, S. (Eds.) (2012). The wealth of the commons: A world beyond market and state. Amherst, MA: Levellers Press.

Canadian Social Economy Research Partnership. (n.d.). Building and Strengthening Communities through the Social Economy. Victoria, BC: University of Victoria. Retrieved from http://socialeconomyhub.ca/sites/socialeconomyhub.ca /files/socialeconomybookletenfinal.pdf.

Carolan, M. (2017). No one eats alone: Food as a social enterprise. Washington: Island Press.

Certomà, C., \& Tornaghi, C. (2015). Political gardening. Transforming cities and political agency. Local Environment: The International Journal of Justice and Sustainability, 20(10), 1123-1131.

City of Victoria. (2016). Community gardens policy. Retrieved from http://www.victoria.ca/assets/Community/Growing in the City/Community\%20 Gardens\%20Policy_Revised\%202016.pdf 
Crouch, D., \& Ward, C. (1988). The allotment: Its landscape and culture. London: Faber and Faber.

Department for Communities and Local Government, UK (2011). Community orchards case studies. Retrieved from https://assets.publishing.service.gov.uk/government/uploads/ system/uploads/attachment_data/file/5908/19732401.pdf.

Eizenberg, E. (2012). Actually existing commons: Three moments of space of community gardens in New York City. Antipode, 44(3), 764-782.

Follmann, A., \& Viehoff, V. (2015). A green garden on red clay: Creating a new urban common as a form of political gardening in Cologne, Germany. Local Environment: The International Journal of Justice and Sustainability, 20(10), 1148-1174.

Ghose, R., \& Pettygrove, M. (2014). Urban community gardens as spaces of citizenship. Antipode, 46(4), 1092-1112.

Guthman, J. (2008). Neoliberalism and the making of food politics in California. Geoforum, 39(3), 1171-1183.

Harvey, D. (2012). Rebel cities. New York: Verso.

Hassanein, N. (2003). Practicing food democracy: A pragmatic politics of transformation. Journal of Rural Studies, 19(1), 77-86.

Heynen, N. (2012). Food justice, hunger and the city. Geography Compass, 6(5), 304-311.

Huron, A. (2015). Working with strangers in saturated space: Reclaiming and maintaining the urban commons. Antipode, 47(4), 963-979.

Hyde, L. (2007). The gift: Creativity and the artist in the modern world ( $\left.2^{\text {nd }} \mathrm{ed}.\right)$. Toronto: Random House.

Johnston, J. (2008). Counterhegemony or bourgeois piggery? Food politics and the case of FoodShare. In W. Wright \& G. Middendorf (Eds.), The fight over food: producers, consumers, and activists challenge the global food system (pp. 93-120). University Park: Pennsylvania State University Press.

King, A., \& Clifford. S. (2011). Community orchards handbook. Dorset, England: Green Books.

Linebaugh, P. (2008). The Magna Carta manifesto: Liberties and commons for All. Berkeley and Los Angeles: University of California Press.

Linn, K. (2007). Building commons and community. Oakland, CA: New Village Press.

Magdoff, F. (2012). Food as a commodity. Monthly Review, 63(8). Retrieved from http://monthlyreview.org/2012/01/01/food-as-a-commodity

McClintock, N. (2010). Why farm the city? Theorizing urban agriculture through a lens of metabolic rift. Cambridge Journal of Regions, Economy and Society, 3, 191-207.

McClintock, N. (2014). Radical, reformist, and garden-variety neoliberal: Coming to terms with urban agriculture's contradictions. Local Environment: The International Journal of Justice and Sustainability, 19(2), 147-171. 
McKay, G. (2011b, May 2). Radical plots: The politics of gardening. The Independent. Retrieved from http://www.independent.co.uk/property/gardening/radical-plots-the-politics-ofgardening-2277631.html.

McMurtry, J. (2001). The life-ground, the civil commons and the corporate male gang. Canadian Journal of Development Studies, 22, 819-854.

Nordahl, D. (2009). Public produce: The new urban agriculture. Washington, Covelo, London: Island Press.

Nordahl, D. (2014). Public produce: Cultivating our parks, plazas, and streets for healthier cities. Washington, Covelo, London: Island Press.

Ostrom, E. (1990). Governing the commons: The evolution of institutions for collective action. Cambridge, UK: Cambridge University Press.

Perkins, H. (2009). Out from the (green) shadow? Neoliberal hegemony through the market logic of shared urban environmental governance. Political Geography, 28(7), 395-405.

Pudup, M. B. (2008). It takes a garden: Cultivating citizen-subjects in organized garden projects. Geoforum, 39, 1228-1240.

Quilligan, J. (2012). Why distinguish common goods from public goods? In D. Bollier \& S. Helfrich (Eds.), The wealth of the commons. A world beyond market and state (pp. 7381). Amherst, MA: Levellers Press.

Rosset, P.M. (2006). Food is different: Why the WTO should get out of agriculture (Global issues). London, UK: Zed Books.

Rosol, M. (2011). Community volunteering as neoliberal strategy? Green space production in Berlin. Antipode, 44(1), 239-257.

Rosol, M. (2018). Politics of urban gardening. In K. Ward, Andrew, E.G. Jonas, B. Miller, \& David Wilson (Eds.), The Routledge Handbook on Spaces of Urban Politics (pp. 134145). New York: Routledge.

Stavrides, S. (2016) Common space: The city as commons. London: Zed Books.

Tornaghi, C. (2014). Critical geography of urban agriculture. Progress in Human Geography, 38(4), 551-567.

Vivero Pol, J.L. (2013). Food as a commons: Reframing the narrative of the food system. SSRN Working paper series. Retrieved from http://papers.ssrn.com/sol3/papers.cfm? abstract_id=22555447

Welsh, J., \& MacRae, R. (1998). Food citizenship and community food security: lessons from Toronto, Canada. Canadian Journal of Development Studies/Revue Canadienne d'Etudes du Développement, 19(4), 237-255.

Wilson, A.D., (2013). Beyond alternative: Exploring the potential for autonomous food spaces. Antipode, 45(3), 719-737. 